\title{
The Development Strategy Batik Seng Village as a Community Based and Creative Tourism Destination in Malang District
}

\author{
Rr. Dewi Ari Setiyowati* Syarif Hidayatullah \\ Merdeka University, 62-64 Terusan Dieng Street, Malang, East Java, Indonesia
}

\begin{abstract}
The tourism sector is a leading sector for the Indonesian economy. The tourism sector is able to spur economic growth, such as opening business opportunities in the tourism sector, be it accommodation, transportation or souvenir centers and new tourist destinations, besides that the tourism sector also opens job opportunities in the tourism sector. Kampung Batik Seng, which is located in Kepanjen, has been established since 2014, this year is the 6th year Batik Seng is listed as one of the batik villages in Malang Regency. Kampung Batik Sengguruh is a tourist destination that is managed independently by the Batik Community in Sengguruh Village by empowering mothers, fathers and youth organizations to produce batik which is then displayed in galleries. In addition, there are packages offered to attract tourists to the production sites. This study is attempt to investigate and identify what are the internal and external factors related to the development of community-based creative tourism destinations and what are the suitable strategies for developing Kampung Batik Seng. The results of this study shows that Internal factors that exist in Kampung Batik Seng. Its strength is the existence of a solid community and the uniqueness of natural batik that characterizes batik in Batik Seng Village. Meanwhile, the biggest weakness in Kampung Batik Seng is the lack of promotion of Kampung Batik Seng. External factors in Kampung Batik Seng. Opportunities are the market that is still wide open, the number of visitors who have come to the location and easy road access. While the existing threats are the absence of guidance from the Tourism Office and the Tourism Village Communication Forum, competitors with the concept of education and the existence of the Covid-19 pandemic. And the strategy that is suitable for the development of Kampung Batik Seng is a diversification strategy, namely the community, community and village parties make plans for the development of Kampung Batik Seng with a different concept from competitors.
\end{abstract}

Keywords: creative tourism destination, development strategies, diversification strategies

DOI: $10.7176 / \mathrm{JTHS} / 58-03$

Publication date:August $31^{\text {st }} 2021$

\section{Introduction}

The tourism sector is the leading sector for Indonesian economic. Tourism is interconnected with one another and influences each other. Tourism is a source of community dynamics and contribute to social and cultural changes in society. Currently the community is involved in every development of a tourist attraction, the community will get a return from what they do. One of them is creative tourism which is an option for tourists. Currently, in addition to refreshing and having fun, tourist also wants new experiences on their tourism activities, tourist can find new experiences and try new things. Creative tourism is preferred by tourist because they can get different experiences so that will be remembered when they back to their own city or country. I developing creative tourism, the manager should maintain the culture and local wisdom that these tourist attractions have. Currently, the government of Malang Regency is collaborating to develop local batik in the region, this was greeted positively by one of the batik groups, Batik Seng, with the theme of their batik village establishing a Destination with Batik Tourism Attraction. Malangan local batik continues to show its existence. Several batik communities have made the production location a tourist attraction. This has the intention of introducing regional batik and improving the economy of the population around the batik production location. Kampung Batik Seng, which is located in Kepanjen, has been established since 2014, this year is the 6th year Batik Seng is listed as one of the batik villages in Malang Regency. Kampung Batik Sengguruh is a tourist destination that is managed independently by the Batik Community in Sengguruh Village by empowering mothers, fathers and youth organizations to produce batik which is then displayed in galleries. In addition, there are packages offered to attract tourists to the production sites. Tourist destination managers provide batik experiences to tourists who come to Kampung Batik Seng to provide a different experience for tourists. Apart from the experience of making batik, tourists can see how to make dyes which are still relatively rare in other batik villages. Batik in Kampung Batik Seng has a deep history and is unique in that it uses natural dyes that are rarely found in other places. The natural dyes used are waste from coffee which is widely available there. In addition, the motifs in Kampung Batik Seng have their own meaning and philosophy so that tourists who come can see the differences between the existing motifs and the batik motifs from other regions, namely the water hyacinth motif which is indeed widely available in Sengguruh Dam In addition, there are apple motifs and flora motifs which indicate that Batik Seng originated from the Malang region. This batik tourism area is a new area with the concept of community empowerment which is still not too prominent compared to the batik tourism areas in other cities such as 
Jogjakarta and Pekalongan. This is because the original livelihoods of the surrounding community are farmers and the batik industry in Malang has only been promoted in recent years, so batik has not been in great demand. The development of the batik village is currently under the supervision of Prof. Wahyudi as the originator, but now it is starting to get the spotlight from the village government. The village government began to pay attention to Kampung Batik Seng because this village provides a different atmosphere and can improve the economy of the surrounding community. As a creative destination, Greg Ricard (2000) explains that creative tourism comes from local cultures in tourist areas. Creative tourism has the potential to take advantage of local skills, expertise and traditions from many regions. Kampung Batik Seng is rooted in the wisdom of local culture in Sengguruh which has the potential to utilize local skills, expertise and traditions as a tourism area for Creative Tourism. Batik making with natural dyes is a tourist attraction, this is evidenced by the number of tourists who come to see the process of making batik using natural dyes that can be found in Kampung Batik Seng.

\section{Tourism Destination}

A tourism destination is a meeting point of supply and demand that is united geographically to combine supply into tourism product. Destination are typically characterized by direct top down management pattern, strong administrave controls and clear lines of authority as ussual in an intraorganizational context. The context of destination types such as, communit, leadership, stategy and task to ensure common goals are usually called DMO ( Destination Management Organization) activities which are based on a stakeholder-oriented management approach. Most of the government's attention on destinations has become a product of interest in the potential profitability and management of tourist destinations in the form of a network. According to Dredge (2006) 'suggests that industrial network companies and DMOs that manage these networks are important elements for the development of sustainable and competitive tourist destinations. According to the meaning of The World Tourism Organization (WTO) is a location where visitors spend at least one night and are packaged in a tourism product that is supported by supporting services as well as tourism attractions and resources, and has territorial boundaries, both physically and administratively that shows an image and

Perceptions of market competitiveness. Meanwhile, according to Supriadi (2017), tourism destinations are a form of a set of tourist attractions that are systemically related along with all the supporting elements such as: accessibility, amenities, local communities and other supporting elements that work synergistically in one integrated system, support and complement. The definitions above can be concluded that a tourist destination is a set of related tourist attractions equipped with various complementary elements and visitors can spend at least 1 night at that location.

\section{Tourism Destination Development Strategy}

According to Pearce and Robinson (2008) Strategy is a large-scale plan, which aims to the future to interact with competitive conditions in order to achieve company goals. Strategy is an overall approach that deals with implementing ideas, planning, executing an activity within a certain period of time. In a good strategy there is work team coordination, has a theme, identifies supporting factors that are in accordance with the principles of implementing ideas rationally, is efficient in funding and has tactics in achieving goals effectively.

According to Cooper, Fletcher, Gilberth, Shepherd and Wanhill (1998) that the tourism development development framework must include several main components that have been determined as follows:

\subsection{Objects and attractions (Attraction)}

Which includes: natural, cultural, artificial, event-based attraction or what is often referred to as special interest 3.1.1 Accessibility

Which includes support for the transportation system, which includes routes, terminal facilities, airports, ports and other modes of transportation

\subsubsection{Amenities}

which include tourism support facilities such as accommodation, restaurants, retail, souvenir shops, money exchange facilities, bus trips / shuttles, tourist information centers and other convenience support facilities.

3.1.3 Supporting facilities (Ancillary Services)

such as the availability of banks, post, telecommunication hospitals and so on

3.1.4 Institutions.

Related to the existence and role of each element in supporting the implementation of tourism activities, including the local community as the host.

A tourism destination development strategy can be based on a market development strategy or a product development strategy. In this case it refers to Anshoff's theory which is simplified in the form of a matrix below. 


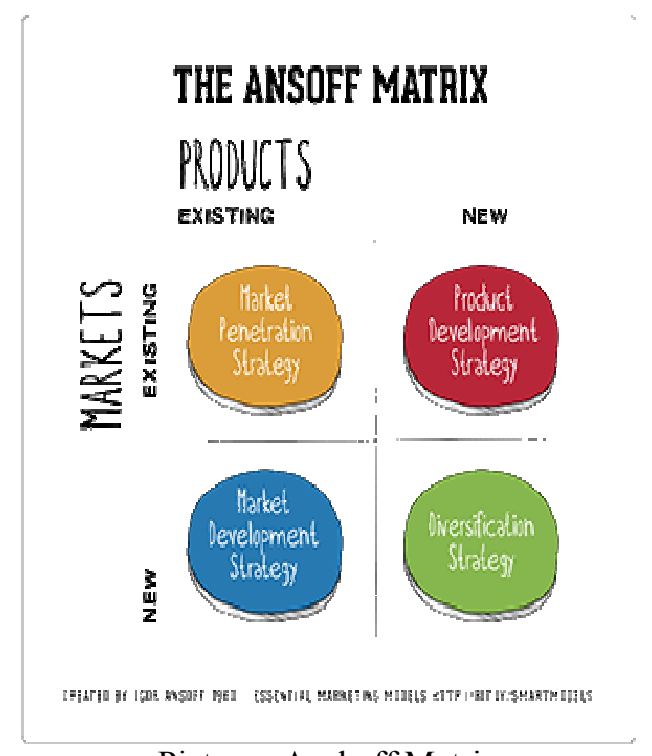

Picture . Anshoff Matrix

From the matrix above, there are four strategies that can be implemented by tourism destinations in the development process, namely:

a) Market penetration

Market penetration is a strategy that focuses on selling products that are already on the market with less risk than other strategies. In terms of developing tourist destinations, tourist destinations can make packages that are common in other tourist locations.

b) Market development

Market development is a strategy whereby the sale of an existing product to a wider market. In terms of tourist destinations, market development can be done by means of promotion using social media so that tourists from other regions and other countries can come to these tourist destinations.

c) Product development

Product development is a strategy in which sellers offer new products to existing markets.

d) Product diversification

Product diversification is a strategy where tourist destinations make products that are completely new and different from products they had before.

\section{Creative Economy}

The concept of the creative economy is an economic concept in the new economic era that intensifies information and creativity by relying on ideas and stock of knowledge from Human Resources (HR) as the main production factor in economic activities. The structure of the world economy is experiencing rapid change and growth, in line with the economic growth that was originally based on natural resources to human resources, from the agricultural era to the industrial and information era.

In the creative economy, batik is part of the scope of cultural arts related to crafts. Batik is one type of decorative cloth typical of Indonesia. Initially, batik has a main function as clothing material, but along with the dynamics of the times, batik is also used as interior accessories and other possible functional uses. The activity of making batik has economic prospects as a creative industry that can absorb a lot of labor. A report by the Organization for Economic Co-Operation and Development (2014) on Tourism and the Creative Economy shows that many countries and regions are now positioning the creative industry as a driver for tourism and other export-oriented activities. As well as expanding the traditional scope such as "cultural tourism" or "heritage tourism" to new areas that are supported by contemporary creativity, such as music, design, fashion and gastronomy. Therefore, in the future, creative tourism will become an area of convergence as a development policy area, which does not focus on tourism growth but also on how tourism can contribute to the creativity of tourists and local communities.

\section{Community Based Tourism}

CBT (Community - Based Tourism) is the concept of developing a tourist destination through empowering local communities, where people take part in planning, managing, and giving votes in the form of decisions in development. There are three tourism activities that can be carried out in community based tourism: exploration (adventure travel), cultural tourism (cultural tourism), ecotourism (ecotourism).

Suansri (2011) defines Community-Based Tourism in a simpler way, namely tourism activities that 
recognize community potential, support community activities and promote community activities in the world of tourism. In addition, there are a number of characteristics of a Community Based Tourism according to Naskun (2011), namely:

a) Because of its character which is easier to organize on a small scale, this type of tourism is basically a type of tourism that is friendly to the environment, is ecologically safe and does not cause many negative impacts like that generated by massive scale conventional tourism types.

b) Community-based tourism has a better chance of being able to develop small-scale tourist objects and attractions, therefore it can be managed by local communities and entrepreneurs, causing minimal socio-cultural impact, and thus having more opportunities. great to be accepted by society

c) Very closely related and as a consequence of both, more than massive conventional tourism, communitybased alternative tourism provides greater opportunities for the participation of local communities to involve themselves in the decision-making process and in enjoying the benefits of the development of the tourism industry, therefore more empowering the community.

Thus, community-based creative tourism is a tourism activity that involves tourists to come up with their creative ideas by participating in activities carried out by a community where these tourism activities take place.

\section{Internal Factor}

Internal factors are factors in the form of tourist objects which include strengths and weaknesses in attracting tourists. Analysis of internal factors including strengths and weaknesses is carried out to determine the internal conditions of the area. According to Pearce \& Robinson (2011) strength is a resource or capability that is controlled or available to a company which makes the company relatively superior to its competitors in meeting the needs of the customers it serves. Meanwhile, weakness is a limitation or deficiency in one or more resources or capabilities of a company compared to its competitors, which becomes an obstacle in meeting customer needs effectively. Internal Factor consists of factors in the form of strengths and weaknesses. This is related to the function of the batik village, management, finance, human resources, marketing, information systems and production.

\section{External Factor}

External factors are factors in the form of tourist attraction which include opportunities (Opportunities) and threats (Threats) in attracting tourists. External analysis which includes opportunities (Opportunities) and threats (Threats) is carried out to determine the position of the region in dealing with the external environment. According to Pearce / Robinson (2011) opportunity is the main situation that is beneficial in the environment of a company, while the threat is the main situation that is not profitable in the environment of a company. External factor data is sought to analyze matters relating to economic, cultural, social, environmental, political demographic, legal, government, technology and market competition issues.

\section{Methode}

\subsection{Descriptive Qualitative}

The research design used a descriptive qualitative approach. A qualitative approach to describe and understand the external and internal factors that influence the development strategy of Kampung Batik Seng in Malang. The location of this research was carried out in Kampung Batik Seng, which is located in Sengguruh Village, Malang Regency. The reason the researchers chose the location of Sengguruh Village as the research location is because Sengguruh Village has its own unique and creative tourism potential, both the Batik cloth produced and the community activities around Sengguruh Village, starting from the Nature School, cultivating catfish and water spinach, making snacks and typical drinks. Sengguruh which is developed into a leading destination. In addition, the people in Kampung Batik Seng also support existing tourism activities.

Data obtained from interviews with informants in the form of visitors, managers, policy makers and local communities at the research location regarding the existing conditions in the location, whether it is strengths, weaknesses, opportunities and threats as well as what strategies have been developed in Kampung Batik Seng. Secondary data were obtained from several agencies related to this research. These data are in the form of: Data on government policies concerning tourism; tourism infrastructure facilities in the research location; tourist visit data; geographic and demographic circumstances; socio-cultural and economic data, etc. Primary data sources can be said to be informants, the criteria of the informants in this study are parties related to and involved with the development of Kampung Batik Seng and the tourism process in Kampung Batik Seng, including the managers of the Batik Village, the batik makers at the Batik Tourism Village location, , Tourism Office staff, policy holders in the Batik Tourism Village area, Paguyuban PAKERTEN engaged in batik as well as tourists in the research location. Then the secondary data sources include field notes, documents. The determination of the informants in this study was carried out by using purposive sampling technique, so that the data obtained from the informants were in accordance with the needs and objectives of the study. 
The data collection procedure is the most important step in research, because the purpose of the study is to obtain data. Data collection was carried out in a variety of settings, sources and methods.

8.1.1 Participatory Observation

Researchers are involved with the daily activities of Kampung Batik Seng and its people, which in this study are being observed and used as a source of research data.

8.1.2 Interview

The interview technique was carried out to obtain subjective knowledge that was understood by the informants regarding the topic being studied. Interviews were conducted with the community using a purposive sampling technique. The consideration of determining informants was carried out by considering conditions in the field, costs, personnel or the time of the interview.

In-depth interviews were conducted to obtain information by exploring facts in the field and experiences experienced by key informants. In this study, 7 key informants were interviewed.

a) 1 formal figure (Village Head, RW Chair)

b) informal leaders (community leaders, religious leaders) 1 person

c) Batik Village Forum (Management and members) 1 person

d) Village community 1 person

e) Office of Culture and Tourism 1 person

f) Association of 1 competent batik workers

g) 1 person tourist

\subsection{Analysis 4 A 1 I Tourist destinations}

1. Objects and attractions (Attraction) in Kampung Batik Seng are cultural attractions, namely batik activities there with unique natural dyes that use 15 types of natural dyes for batik products, including Indigo, Pinang, Safflower, Turmeric, Suji Leaves and Mangosteen Skin. In addition, the Nature School which is a school with the concept of blending with nature, the first in Malang is also an attraction in Batik Seng Village. water which is usually used for weddings and events one suro

2. The route accessibility to Kampung Batik Seng is quite easy if from the city center of Malang it can be reached for 45 minutes to the south to Kepanjen, a location that is easily accessible by private vehicles, mini buses or large buses. If you want to go to Kampung Batik Seng by using public transportation, you can take the City Transportation from Malang to the Gadang Terminal, then continue by taking the City Transportation or riding a horse-drawn carriage or Dokar. The roads are also good and there are not many holes

3.Amenitas (Amenities) which are included in the tourism support facilities in Kampung Batik Seng Homestay which are provided in residents' homes, but there are only 3 houses that meet the proper requirements for bathrooms. In addition, there are souvenir shops and souvenirs, both batik masks and puppets. There are no restaurants and money exchange facilities, however, if tourists want to eat in the area, the manager prepares a tour package as well as a meal.

4. Supporting facilities (Ancillary Services) in Kampung Batik Seng are close to the Puskesmas and doctor's clinic, so that in case of emergency, tourists can be rushed to the two health facilities.

5. The institution (institution) in Kampung Batik Seng is still focused on the management of the batik village, because the tourism awareness group is still newly formed so that it is still not running optimally. Regarding the existence and role of each element, both the village government has been very supportive of the activities in Kampung Batik Seng. In addition, the local community and community play an active role in supporting the implementation of tourism activities in Kampung Batik Seng.

\subsection{External Factor Analysis System and Internal Factor Analysis System}

Tourism is a very significant community development tool. Especially for rural communities. Therefore, cooperation from various parties such as the government, the private sector, educational and training institutions as well as the community itself is very necessary. There are several factors of strengths, weaknesses, threats and opportunities resulting from the interview process. The researchers summarize these factors in the following tables. 
Table 1. Strength factor of Kampung Batik Seng

\begin{tabular}{|l|l|l|}
\hline No & Stregth & Description \\
\hline 1 & Have solid association & $\begin{array}{l}\text { The association consisting of profesors, batik assessors and } \\
\text { residents who have mission to make Kampun Batik Seng as a } \\
\text { Tourist destination }\end{array}$ \\
\hline 2 & Has a peculiarity batik & Batik product in Kampung Batik Seng is batik with natural dyes \\
\hline 3 & $\begin{array}{l}\text { Word of mouth has been done by } \\
\text { various parties }\end{array}$ & $\begin{array}{l}\text { Word of mouth promotion, began from Mr. Wahyudi Guest both } \\
\text { domestic and foreign }\end{array}$ \\
\hline 4 & $\begin{array}{l}\text { Has a unique culture and school with a } \\
\text { natural based }\end{array}$ & $\begin{array}{l}\text { The Al-Ikhlas Nature School is the concept of the first nature } \\
\text { school in East Java }\end{array}$ \\
\hline 5 & $\begin{array}{l}\text { The community is open to tourism } \\
\text { activities }\end{array}$ & $\begin{array}{l}\text { People who participate when there are tourist visits and act as } \\
\text { teachers and providers of consumption }\end{array}$ \\
\hline 6 & $\begin{array}{l}\text { Coordination between the community } \\
\text { and the village goverment began to } \\
\text { take place }\end{array}$ & $\begin{array}{l}\text { During this period the Village goverment Head was very } \\
\text { supportive of the development of Kampung Batik Seng as a } \\
\text { tourist destination }\end{array}$ \\
\hline 7 & $\begin{array}{l}\text { Covid 19 Protocol is Available in } \\
\text { Kampung Batik Seng area }\end{array}$ & $\begin{array}{l}\text { Kampung Batik Seng has implemented the Covid -19 protocol, } \\
\text { be it a hand washing area, hand sanitizer, and masks which are } \\
\text { also souvenirs for tourists }\end{array}$ \\
\hline
\end{tabular}

Table 2. Weakness Factors of Kampung Batik Seng

\begin{tabular}{|c|c|c|}
\hline No & Weakness & Description \\
\hline 1 & Lack of online promotion & $\begin{array}{l}\text { There is already a website but it is not well managed and offline } \\
\text { marketing is rarely done, so that Batik Seng Village is not well known } \\
\text { by Malang residents }\end{array}$ \\
\hline 2 & $\begin{array}{l}\text { Human resources to serve } \\
\text { tourists are still weak }\end{array}$ & $\begin{array}{l}\text { Existing human resources have not received tourism training either by } \\
\text { the private sector or the governmen }\end{array}$ \\
\hline 3 & $\begin{array}{l}\text { There is no comprehensive } \\
\text { tour package }\end{array}$ & The only package offered is the batik education package \\
\hline 4 & $\begin{array}{lrr}\text { Tourism facilities } & \text { and } \\
\text { infrastructure } & \text { are } & \text { not } \\
\text { supportive yet } & \end{array}$ & $\begin{array}{l}\text { Facilities such as the sign of Kampung Batik Seng are not clearly visible } \\
\text { and there are no signposts to Kampung Batik and for tourism objects, } \\
\text { there is not enough homestays available and there is no restaurant that } \\
\text { capable for many people }\end{array}$ \\
\hline 5 & $\begin{array}{l}\text { There is no collaboration with } \\
\text { the Indonesian Tourism } \\
\text { Guides Association }\end{array}$ & $\begin{array}{l}\text { There is no collaboration with Indonesian Tourist Guide Association, } \\
\text { which is first marketing of tourism in an area. }\end{array}$ \\
\hline
\end{tabular}

Table 3. The Opportunity Factors of Kampung Batik Seng

\begin{tabular}{|l|l|l|}
\hline No & Oportunity Factor & Description \\
\hline 1 & Market still open & $\begin{array}{l}\text { with the concept of batik education, there are many tourist has interest to } \\
\text { learning about batik, which is Indonesian culture }\end{array}$ \\
\hline 2 & Many visitors have come & $\begin{array}{l}\text { The presence of many visitors who come indicates that many enthusiasts } \\
\text { of batik education tours and nature schools, and they will come if we do } \\
\text { properly promotions. }\end{array}$ \\
\hline 3 & $\begin{array}{l}\text { Easy road access and there is } \\
\text { a parking space for the bus }\end{array}$ & $\begin{array}{l}\text { The road access to Kampung Batik Seng is easy and the parking lot for } \\
\text { buses makes it easier for tourists, both independent and groups, to come to } \\
\text { Kampung Batik Seng }\end{array}$ \\
\hline
\end{tabular}

Table 4. The Threat Factors of Kampung Batik Seng

\begin{tabular}{|l|l|l|}
\hline no & Threat Factor & Description \\
\hline 1 & $\begin{array}{l}\text { There has been no follow-up from the Tourism } \\
\text { Office and the Tourism Village Communication } \\
\text { Forum }\end{array}$ & $\begin{array}{l}\text { The absence of follow-up from the Tourism Office } \\
\text { and Tourism Village Communication Forum }\end{array}$ \\
\hline 2 & There are competitors with the concept of education & $\begin{array}{l}\text { The existence of competitors with the concept of } \\
\text { batik education in Malang has made some tourists } \\
\text { choose to visit closer places }\end{array}$ \\
\hline 3 & The Covid-19 pandemic & $\begin{array}{l}\text { The Covid-19 pandemic has made Kampung Batik } \\
\text { Seng experience a decline in income }\end{array}$ \\
\hline
\end{tabular}


The following is an analysis to determine internal and external factors through steps:

1. Determination of the Rating Weight

After identifying the four internal and external factors, they are processed in tabular form to obtain the weight and rating of each factor. After the data is obtained, the data is processed again to obtain the weight value and average rating of each factor

2, Rating Determination

Data obtained from interviews of each the association of competent batik workers expert, the Tourism Office, the Head of communication forum for Tourism Village, the Chairperson of Indonesian Guide Assosiation in Malang, and Prof. Wahyudi as an academic in the field of culture and tourism then processed in one table to get an average score. The table is divided into 2, namely internal and external factors. The first step that must be taken is processing the internal strategic factor rating. The results of the rating calculations for internal actors are presented in table 5 .

Table 5. Mean Internal Factor Score

\begin{tabular}{|c|c|c|c|c|c|c|c|}
\hline \multirow{2}{*}{$\begin{array}{l}\text { Internal factors } \\
\text { Strengths - Weaknesses }\end{array}$} & \multicolumn{5}{|c|}{$\begin{array}{ll}\text { Key } & \text { Informant } \\
\text { Ratings } & \\
\end{array}$} & \multirow{2}{*}{$\begin{array}{l}\text { Total } \\
\text { Score }\end{array}$} & \multirow{2}{*}{$\begin{array}{l}\text { Mean } \\
\text { Score }\end{array}$} \\
\hline & 1 & 2 & 3 & 4 & 5 & & \\
\hline \multicolumn{8}{|l|}{ Strengths } \\
\hline Have a solid community (a) & 4 & 4 & 4 & 4 & 4 & 20 & 4 \\
\hline Has a Batik Distinctiveness (b) & 3 & 4 & 4 & 4 & 3 & 18 & 3,6 \\
\hline Word of Mouth Marketing (c) & 4 & 3 & 3 & 4 & 4 & 18 & 3,6 \\
\hline Has a unique culture $(\mathrm{d})$ & 3 & 3 & 4 & 4 & 4 & 18 & 3,6 \\
\hline The community is open to tourism activities (e) & 4 & 3 & 4 & 4 & 3 & 18 & 3,6 \\
\hline Community coordination with the batik village (f) & 4 & 3 & 4 & 4 & 3 & 18 & 3,6 \\
\hline \multicolumn{8}{|l|}{ Weaknesses } \\
\hline Lack of marketing promotion for Kampung Batik (g) & 4 & 3 & 4 & 4 & 4 & 19 & 3,8 \\
\hline Human resource ability to serve tourists is weak (h) & 3 & 3 & 3 & 3 & 3 & 15 & 3 \\
\hline There is no comprehensive tour package yet (i) & 3 & 3 & 3 & 3 & 3 & 15 & 3 \\
\hline The infrastructure is not yet supported (j) & 2 & 3 & 2 & 3 & 3 & 13 & 2,6 \\
\hline $\begin{array}{l}\text { There has been no cooperation with the Indonesian Tour Guides } \\
\text { Association }(\mathrm{k})\end{array}$ & 3 & 3 & 4 & 3 & 3 & 16 & 3,2 \\
\hline
\end{tabular}

In table 5. The results show that the highest value of the internal strength factor is 4.00, namely a solid association which, according to Mr. Anshori, as the Chair of the East Java Tourism Village Communication Forum, is a must-have when opening a tourist village. As for the internal factor of weakness, the highest score is in the lack of tourism promotion in the tourist village with a value of 3,8 . Things that must be improved from tourism promotion must be started with the creation of a clear tour package that contains what facilities are obtained and how long tourists will spend in Kampung Batik Seng.

Table 6. Mean Score of External Factors

\begin{tabular}{|c|c|c|c|c|c|c|c|}
\hline \multirow[t]{2}{*}{ External Factors } & \multicolumn{5}{|c|}{$\begin{array}{l}\text { Key Informant } \\
\text { Ratings }\end{array}$} & \multirow{2}{*}{$\begin{array}{l}\text { Total } \\
\text { Score }\end{array}$} & \multirow{2}{*}{$\begin{array}{l}\text { Average } \\
\text { Score }\end{array}$} \\
\hline & 1 & 2 & 3 & 4 & 5 & & \\
\hline \multicolumn{8}{|l|}{ OPPORTUNITIES } \\
\hline The tourist market is still open (a) & 4 & 4 & 4 & 4 & 4 & 20 & 4 \\
\hline There have been many visitors (b) & 4 & 4 & 4 & 4 & 3 & 19 & 3,8 \\
\hline Easy road access $(\mathrm{c})$ & 4 & 4 & 4 & 4 & 4 & 20 & 4 \\
\hline \multicolumn{8}{|l|}{ TREATH } \\
\hline $\begin{array}{l}\text { There has been no follow up from the Tourism Office and the } \\
\text { Tourism Village Communication Forum }(\mathrm{d})\end{array}$ & 4 & 4 & 4 & 4 & 4 & 20 & 4 \\
\hline There are competitors with similar concepts (e) & 4 & 4 & 4 & 4 & 4 & 20 & 4 \\
\hline The Covid-19 pandemic (f) & 4 & 4 & 4 & 4 & 4 & 20 & 4 \\
\hline
\end{tabular}

Based on table 6 , information is obtained about external factors including opportunities and threats. The highest average score for threats is 4 , namely the tourist market which is still open and easy road access makes Batik Seng Village have to improve itself so that more tourists visit Batik Seng Village. While the external factors of the three threats have a value of 4, meaning that these threats must really be considered and followed up so that in the future the development of Kampung Batik Seng can run.

Table 7.

Weighting of Internal and External Factors

The weighting of internal and external factors is obtained from the assessment of which level of importance is more important and which is equally important and which is not more important. The results are obtained from 
the sum of the scores for each factor which is then divided by the total score for each factor. Then the ranking is determined from the largest to the smallest which is shown in table 7.

Table 7. Weighting of internal factors

\begin{tabular}{|c|c|c|c|c|}
\hline INTERNAL FACTOR & Weigh & Ratin & Scor & Cod \\
\hline STREGHT & $\mathrm{t}$ & $\mathrm{g}$ & $\mathrm{e}$ & $\mathrm{e}$ \\
\hline Have a solid community (a) & 0,25 & 4 & 1 & S1 \\
\hline Has a Batik Distinctiveness (b) & 0,2 & 3,6 & 0,72 & S2 \\
\hline Word of Mouth Marketing (c) & 0,15 & 3,6 & 0,54 & S3 \\
\hline Has a unique culture $(\mathrm{d})$ & 0,1 & 3,6 & 0,36 & S4 \\
\hline The community is open to tourism activities (e) & 0,15 & 3,6 & 0,54 & S5 \\
\hline Community coordination with the batik village (f) & 0,15 & 3,6 & 0,54 & S6 \\
\hline Total & 1 & & 3,7 & \\
\hline \multicolumn{5}{|l|}{ WEAKNESS } \\
\hline Lack of marketing promotion for Kampung Batik (g) & 0,25 & 3,8 & 0,95 & W1 \\
\hline Human resource ability to serve tourists is weak $(\mathrm{h})$ & 0,15 & 3 & 0,45 & W2 \\
\hline There is no comprehensive tour package yet (i) & 0,25 & 3 & 0,75 & W3 \\
\hline The infrastructure is not yet supported (j) & 0,3 & 2,6 & 0,78 & W4 \\
\hline $\begin{array}{l}\text { There has been no cooperation with the Indonesian Tour Guides Association } \\
(\mathrm{k})\end{array}$ & 0,05 & 3,2 & 0,16 & W5 \\
\hline Total & 1 & & 3,09 & \\
\hline
\end{tabular}

Based on table 7, it can be seen that the highest score that is owned by the internal factor of strength is a solid community and the second is that it has the uniqueness of natural batik that can be sold and becomes a superior product in Kampung Batik Seng. Meanwhile, from internal factors, the highest score was the lack of marketing promotion in Kampung Batik Seng. Actually the association has made leaflets and pamphlets for promotion obtained from students who are interns or Fieldwork Practices in Batik Seng Village, however, because the tourism awareness group has not been functioning optimally, these leaflets and pamphlets have not been able to be an effective promotional tool. Apart from the leaflet, there is the Batik Seng website which is also not being used optimally.

Table 8. Weighting of External Factors

\begin{tabular}{|c|c|c|c|c|}
\hline $\begin{array}{l}\text { External Factors } \\
\text { OPORTUNITIES }\end{array}$ & $\begin{array}{c}\text { Weg } \\
\text { ht }\end{array}$ & $\begin{array}{c}\text { Rati } \\
\text { ng }\end{array}$ & $\begin{array}{c}\text { Sco } \\
\text { re }\end{array}$ & $\begin{array}{l}\text { Co } \\
\text { de }\end{array}$ \\
\hline The tourist market is still open (a) & 0,45 & 4 & 1,8 & $\mathrm{O} 1$ \\
\hline There have been many visitors (b) & 0,2 & 3,8 & 0,76 & $\mathrm{O} 2$ \\
\hline Easy road access (c) & 0,35 & 4 & 1,4 & $\mathrm{O} 3$ \\
\hline Total & 1 & & 3,96 & \\
\hline \multicolumn{5}{|l|}{ TREATH } \\
\hline $\begin{array}{l}\text { There has been no follow up from the Tourism Office and the Tourism Village } \\
\text { Communication Forum (d) }\end{array}$ & 0,4 & 4 & 1,6 & $\mathrm{~T} 1$ \\
\hline There are competitors with similar concepts (e) & 0,25 & 4 & 1 & $\mathrm{~T} 2$ \\
\hline The Covid-19 pandemic (f) & 0,35 & 4 & 1,4 & T3 \\
\hline Total & 1 & & 4 & \\
\hline
\end{tabular}

Based on the results of table 8 , it can be seen that the highest score on the external factor of opportunity is the tourist market which is still open, with the recognition of batik as an intangible heritage by UNESCO, schools are required to teach batik to their students, both from elementary school level, junior high school. or high school. In addition, the existence of student exchanges with foreign students is one market share that Kampung Batik Seng can target. With this potential, it is adjusted to make packages that can provide tourists with new experiences when traveling in Kampung Batik Seng.

Meanwhile, the highest score of external threat factors was that there was no follow-up from the Tourism Office and the East Java Tourism Village Communication Forum. This needs to be responded to by holding a group discussion forum by inviting related parties so that coaching can be carried out and the development of Kampung Batik Seng can run. 
Table 9. Difference in Weighted Value of Kampung Batik Seng

\begin{tabular}{|c|c|c|c|}
\hline No & Factor & Information & Score \\
\hline 1 & \multirow[t]{2}{*}{ Internal } & The weighted value of the Strength of Batik Seng Village & 3,7 \\
\hline 2 & & Weakness weighted value of Kampung Batik Seng & 3,09 \\
\hline \multicolumn{3}{|r|}{ Difference is positive } & 0,61 \\
\hline 3 & \multirow[t]{2}{*}{ Eksternal } & Weighted value of Kampung Batik Seng Opportunity & 3,96 \\
\hline 4 & & The weighted value of the threat of Kampung Batik Seng & 4 \\
\hline \multicolumn{3}{|r|}{ Negative Difference } & 0,04 \\
\hline
\end{tabular}

To find out which strategy should be used in the development of Kampung Batik Seng, it is necessary to create a space matrix. Based on the table the difference in the weighted value of the internal factors of Kampung Batik Seng has a positive difference of 0.61 and external factors have a negative difference of 0.04

Image 2. Batik Village SWOT Space Matrix

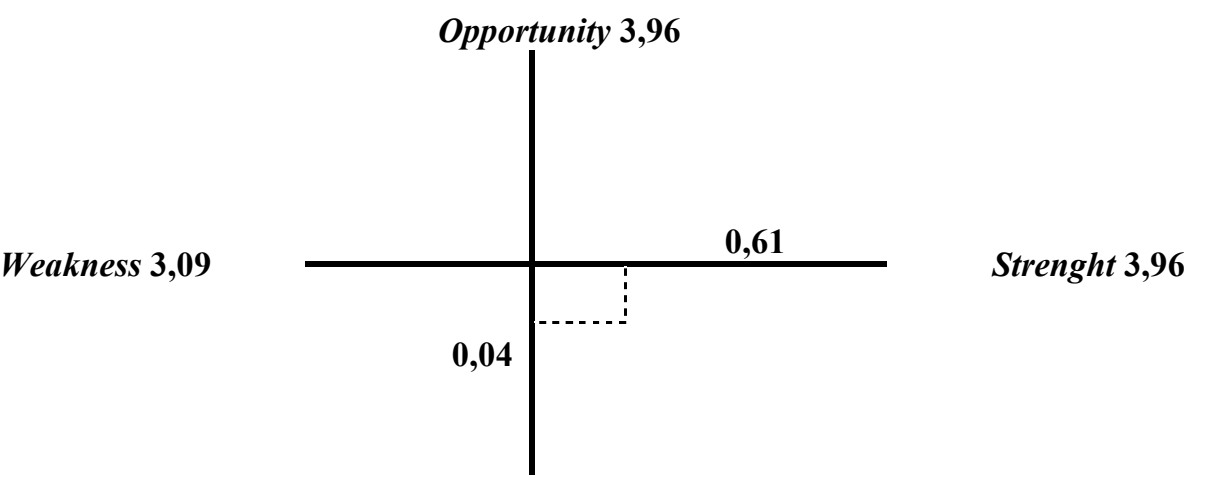

Threath 4

The results of the space matrix in the figure show that to support community-based creative tourism in Kampung Batik Seng, the development strategy used is included in quadrant II, namely Diversification Strategies that utilize strength to overcome threats. Positioning is in quadrant II, development strategies that can be done are;

1. Determine different packages with competitors. Whether it's the education per art package in Kampung Batik Seng or the whole package which is packaged in a 3 day 2 night tour package.

2. Prepare everything needed for the New Normal era, be it the Covid-19 protocol and the readiness of the community to implement the health protocol that has been announced by the government

3. Regular communication with the Tourism Office and the Tourism Village Forkom

4. Prepare the community to participate in tourism activities, be it conducting training and placing work positions.

Kampung Batik Seng has a solid association, good communication with the village can be used to overcome threats that come from the absence of follow-up from the Tourism Office and the Tourism Village Communication Forum. It has the uniqueness of natural batik, besides that word of mouth and an open society with the presence of tourists are a force that can overcome the threat of competitors with similar concepts. Because an existing regional and cultural uniqueness will create a different impression from each tourist spot. By being presented with attractions such as making batik with residents or catching catfish and cooking together, tourists will feel special memories while in Kampung Batik Seng. In addition, the participation of residents and associations who want to provide hand washing places for hand sanitizers and batik makers who produce masks is a force that can overcome the threat of the Covid-19 pandemic that is currently spreading.

\section{Community and Community Based Creative Tourism Development Strategy in Batik Seng Village}

Tourism development is a strategy used to promote, improve and improve the tourism conditions of a tourist object and tourist attraction so that it can be visited by tourists and is able to provide benefits to communities around tourist attractions (Supriadi, 2017). The development of Kampung Batik Seng as a creative and community-based tourism is as follows

a. Arrange different tour packages with competitors

This strategy was chosen to take advantage of the strengths and opportunities of Kampung Batik Segguruh. With the characteristics of batik and the nature school in Kampung Batik Seng and the community of batik craftsmen there, the manager will create a tourist attraction that contains the daily activities of the surrounding community. The tour package will begin by coming to Kampung Batik Seng to make a batik handkerchief, followed by a trip to the location where the shadow puppets are made, there will be taught how the process of making leather puppets from beginning to end after which the tourists are invited to relax and enjoy lunch in the rice fields then 
tourists will invited to walk to the location of catfish hatcheries and mujaer to feed and explained about the irrigation process. Furthermore, tourists are invited to the mask craftsmen to see the process of making masks. And finally tourists will be presented with a dance performance in the Green Open Space area to end the trip. The package can be broken down into 2 days depending on the duration of the traveler. In addition, every day there will also be reog, Barong, Anoman and other traditional dances exercises in turn, so that if tourists want to see these dances tourists can choose to come to Kampung Batik Seng on what day ..

b. Prepare all the necessities for the New Normal era, cooperate with the government in implementing HR training and disseminating Covid-19 prevention to the public.

c. Regular communication with the Tourism Office and the Tourism Village Forkom for the implementation of tourism training and promotion. With us often communicating with the agency, our names will also be remembered and if there is training or activities, Kampung Batik Seng will be provided with information.

d. Prepare the community to participate in tourism activities, be it conducting training or placing work positions.

\section{Conclucion}

Based on the research results it is known that:

1. Internal factors that exist in Kampung Batik Seng. Its strength is the existence of a solid community and the uniqueness of natural batik that characterizes batik in Batik Seng Village. Meanwhile, the biggest weakness in Kampung Batik Seng is the lack of promotion of Kampung Batik Seng

2. External factors in Kampung Batik Seng. Opportunities are the market that is still wide open, the number of visitors who have come to the location and easy road access. While the existing threats are the absence of guidance from the Tourism Office and the Tourism Village Communication Forum, competitors with the concept of education and the existence of the Covid-19 pandemic.

3. The strategy that is suitable for the development of Kampung Batik Seng is a diversification strategy, namely the community, community and village parties make a development plan for Kampung Batik Seng with a different concept from competitors.

\section{References}

A. Yoeti Oka. (2010). Basics of Understanding Hospitality Tourism. Bandung: PT. Alumni

Bogdan, R.C., \& Biklen. (1998). Qualitative Research For Education: An Introduction to Theory and Methodhs. Boston: Allyn and Bacon.

Cooper.C., Fletcher.G., Gilbert.D., Sheperd.R., \& Wanhill.S. (1998). Tourism: Principles and Practice Second Edition. England: Addison-Wesley, Longman

Dredge, Dianne. (1999). Destination Place, Planning and Design. Annals Of Tourism Research. Pergamon

Ministry of Trade RI. (2008). Indonesian Creative Economy Development 2009-2025. Jakarta: Ministry of Trade of the Republic of Indonesia

Freddy Rangkuti. (2005). SWOT Analysis: Techniques for Dissecting Business Cases. Jakarta. PT. Gramedia.

Ilyas, Muhammad. (2009). Tourism Development Strategy for Togean Islands in Tojo Una-Una. Thesis. Makassar: Regional Logging Planning Study Program

Ismayanti .(2010). Introduction to Tourism. Tangerang: Open Universits

Kotler., P. \& Keller., K., L. (2009). Marketing Management 13th Editio. Jakarta: Erlangga

Kusworo, Hendrie A. (2002). Regional Tourism Human Resources. ISSN Journal of Social and Political Sciences

La Ode Unga, Kartini. (2011). Banda Islands Tourism Development Strategy. Makassar: Hasanudin University Graduate Program.

Miles, B. Mathew and Michael Huberman. (1992). Qualitative Data Analysis Resource Book About New Methods. Jakarta: UIP

Nasikun. (1999). Globalization and a New Paradigm of Community-Based Tourism. Workshop on Tourism Arrangement in Welcoming a New Indonesia. Organized by DEPARI, Suaraupdate, and PUSPAR-UGM: Puncaka

Nugroho.I. (2011). Ecotourism and Sustainable Development. Yogyakarta: Student Library

Nasution, S. (2000). Research Methods. Jakarta: Earth Literacy

OECD. (2014). Tourism and The Creative Economic, OECD Studies on Tourism: OECD Publishing

Pickton., David., \& Brodrick., Amanda. (2001). Integrated Marketing Communication. London: Financial Times Prentice Hall.

Priyatmono, A.F. (2012). Development of Community-Based Creative Tourism and Local Culture. Surakarta: National Siposium RAPI XI FT UMS.

Pratama, H.F., \& Sakti.B. (2015). The Strategy for the Development of the Long Beach Tourism Area in Bengkulu, Judging from the Perspective of Tourists and Local Communities. Bengkulu: Postgraduate Program UNIHAZ Bengkulu. 
Pearce II, John A. And Robinson Richard B.Jr. (2008). Strategic Management 10. Jakarta: Salemba Empat Richard, G and Raymond, C. (2000). Creative Tourism. Atlas News.

Shimpi., Terence, A. (2000). Advertising and Promotion of Additional Aspects of Integrated Marketing Communication. Fifth Edition Volume-1. Jakarta: Erlangga

Wrong Wahab. (1992). Tourism Management. Jakarta: Publisher Pradnya Paramita

Suansri, Potjana. (2003). Community Based Tourism Handbook. Thailand: Rest Project

Suwantoro., G. (2004). Basics of Tourism. Yogyakarta: Publisher Andi

Stanton, William J. (2013). Principles of Marketing. Translation by Buchari Alma. Volume one, tenth edition. Jakarta: Erlangga

Suparwoko. (2010). Development of the Creative Economy as a Driving Force for the Tourism Industry in Purworejo Regency, Central Java. National Symposium Towards Dynamic and Creative Purworejo

Supriadi, Bambang \& Roedjinandari, Nanny. (2017). Planning and Development of Tourism Destinations. Malang: State University of Malang

Toffler.A., \& Toffler., P. (1980). Creating a New Civilization: The Politics of Third Wave. Political Science

Widadio, N.A. (2014). The Best Development of Indonesian Tourism. Jakarta: Menparekraf Kompas 